\title{
Front Matter: Volume 8320
}

, "Front Matter: Volume 8320," Proc. SPIE 8320, Medical Imaging 2012: Ultrasonic Imaging, Tomography, and Therapy, 832001 (9 April 2012); doi: 10.1117/12.931587

SPIE. Event: SPIE Medical Imaging, 2012, San Diego, California, United States 


\title{
PROGRESS IN BIOMEDICAL OPTICS AND IMAGING
}

Vol. 13, No. 36

Medical Imaging 2012

Ultrasonic Imaging, Tomography, and Therapy

\author{
Johan G. Bosch \\ Marvin M. Doyley \\ Editors
}

\section{5-6 February 2012 \\ San Diego, California, United States}

Sponsored by

SPIE

Cosponsored by

Agilent Technologies • Diamond SA (Switzerland) - DQE Instruments, Inc. (Canada)

eMagin (United States) • Isuzu Glass Co., Ltd. (Japan) • Medtronic, Inc. • Ocean Thin Films, Inc.

(United States)

Cooperating Organizations

AAPM-American Association of Physicists in Medicine (United States) • CARS—Computer Assisted Radiology and Surgery (Germany) - Medical Image Perception Society (United States) • Radiological Society of North America (United States) - APS—American Physiological Society (United States) • The DICOM Standards Committee (United States) • Society for Imaging Informatics in Medicine (United States) • The Society for Imaging Science and Technology • World Molecular Imaging Society

Published by

SPIE

Volume 8320 
The papers included in this volume were part of the technical conference cited on the cover and title page. Papers were selected and subject to review by the editors and conference program committee. Some conference presentations may not be available for publication. The papers published in these proceedings reflect the work and thoughts of the authors and are published herein as submitted. The publisher is not responsible for the validity of the information or for any outcomes resulting from reliance thereon.

Please use the following format to cite material from this book:

Author(s), "Title of Paper," in Medical Imaging 2012: Ultrasonic Imaging, Tomography, and Therapy, edited by Johan G. Bosch, Marvin M. Doyley, Proceedings of SPIE Vol. 8320 (SPIE, Bellingham, WA, 2012) Article CID Number.

ISSN 1605-7422

ISBN 9780819489692

Published by

SPIE

P.O. Box 10, Bellingham, Washington 98227-0010 USA

Telephone +1 3606763290 (Pacific Time) · Fax +1 3606471445

SPIE.org

Copyright (C) 2012, Society of Photo-Optical Instrumentation Engineers.

Copying of material in this book for internal or personal use, or for the internal or personal use of specific clients, beyond the fair use provisions granted by the U.S. Copyright Law is authorized by SPIE subject to payment of copying fees. The Transactional Reporting Service base fee for this volume is $\$ 18.00$ per article (or portion thereof), which should be paid directly to the Copyright Clearance Center (CCC), 222 Rosewood Drive, Danvers, MA 01923. Payment may also be made electronically through CCC Online at copyright.com. Other copying for republication, resale, advertising or promotion, or any form of systematic or multiple reproduction of any material in this book is prohibited except with permission in writing from the publisher. The CCC fee code is 1605 $7422 / 12 / \$ 18.00$.

Printed in the United States of America.

Publication of record for individual papers is online in the SPIE Digital Library.

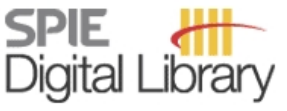

SPIEDigitallibrary.org

Paper Numbering: Proceedings of SPIE follow an e-First publication model, with papers published first online and then in print and on CD-ROM. Papers are published as they are submitted and meet publication criteria. A unique, consistent, permanent citation identifier (CID) number is assigned to each article at the time of the first publication. Utilization of CIDs allows articles to be fully citable as soon as they are published online, and connects the same identifier to all online, print, and electronic versions of the publication. SPIE uses a six-digit CID article numbering system in which:

- The first four digits correspond to the SPIE volume number.

- The last two digits indicate publication order within the volume using a Base 36 numbering system employing both numerals and letters. These two-number sets start with $00,01,02,03,04$, $05,06,07,08,09,0 A, 0 B \ldots 0 Z$, followed by 10-1Z, 20-2Z, etc.

The CID number appears on each page of the manuscript. The complete citation is used on the first page, and an abbreviated version on subsequent pages. Numbers in the index correspond to the last two digits of the six-digit CID number. 


\title{
Contents
}

\author{
xi Conference Committee \\ xiii Fortieth Anniversary of SPIE Medical Imaging Meeting (Overview Paper) \\ R. M. Nishikawa, Carl J. Vyborny Translation Lab. for Breast Imaging Research, The Univ. of \\ Chicago (United States)
}

\section{SESSION $1 \quad$ ULTRASOUND COMPUTER TOMOGRAPHY: NOVEL TECHNOLOGY}

832002 Ultrasound waveform tomography with the total-variation regularization for detection of small breast tumors [8320-01]

Y. Lin, L. Huang, Z. Zhang, Los Alamos National Lab. (United States)

832003 Efficient implementation of ultrasound waveform tomography using source encoding [8320-02]

Z. Zhang, L. Huang, Y. Lin, Los Alamos National Lab. (United States)

$832004 \quad$ Nonlinear inversion modeling for Ultrasound Computer Tomography: transition from soft to hard tissues imaging [8320-03]

P. Lasaygues, S. Mensah, R. Guillermin, J. Rouyer, E. Franceschini, Lab. of Mechanics and Acoustics, CNRS, Aix-Marseille Univ. (France)

832005 Phantom image results of an optimized full 3D USCT [8320-04]

N. V. Ruiter, M. Zapf, T. Hopp, R. Dapp, H. Gemmeke, Karlsruhe Institute of Technology (Germany)

832006 Travel time denoising in ultrasound tomography [8320-05]

O. Roy, C. Li, N. Duric, Delphinus Medical Technologies (United States) and Karmanos Cancer Institute (United States)

\section{SESSION 2 ULTRASOUND IMAGE PROCESSING}

832007 Comparison of spatiotemporal interpolators for 4D image reconstruction from 2D transesophageal ultrasound [8320-06]

A. Haak, Erasmus MC (Netherlands); M. van Stralen, Univ. Medical Ctr. Utrecht (Netherlands); G. van Burken, S. Klein, Erasmus MC (Netherlands); J. P. W. Pluim, Univ. Medical Ctr. Utrecht (Netherlands); N. de Jong, A. F. W. van der Steen, Erasmus MC (Netherlands) and Interuniversity Cardiology Institute of the Netherlands (Netherlands); J. G. Bosch, Erasmus MC (Netherlands)

832008 Adaptive volume rendering of cardiac 3D ultrasound images: utilizing blood pool statistics [8320-07]

J. P. Åsen, Norwegian Univ. of Science and Technology (Norway); E. Steen, GE Vingmed Ultrasound (Norway); G. Kiss, A. Thorstensen, Norwegian Univ. of Science and Technology (Norway) and St. Olavs Hospital (Norway); S. I. Rabben, GE Vingmed Ultrasound (Norway) 
832009 Dynamic shape modeling of the mitral valve from real-time 3D ultrasound images using continuous medial representation [8320-08]

A. M. Pouch, P. A. Yushkevich, B. M. Jackson, J. H. Gorman III, R. C. Gorman, C. M. Sehgal, Univ. of Pennsylvania (United States)

$83200 \mathrm{~A}$ Learning-based scan plane identification from fetal head ultrasound images [8320-09] X. Liu, GE Global Research (United States); P. Annangi, M. Gupta, GE Global Research (India); B. Yu, D. Padfield, GE Global Research (United States); J. Banerjee, K. Krishnan, GE Global Research (India)

8320 OB Model-based coupled denoising and segmentation of medical images [8320-10] A. Tuysuzoglu, GE Global Research (United States) and Boston Univ. (United States); P. Mendonca, D. Padfield, GE Global Research (United States)

8320 OC Motion compensation method using dynamic programming for quantification of neovascularization in carotid atherosclerotic plaques with contrast enhanced ultrasound (CEUS) [8320-11]

Z. Akkus, Erasmus MC (Netherlands); A. Hoogi, Erasmus MC (Netherlands) and TechnionIsrael Institute of Technology (Israel); G. Renaud, G. L. ten Kate, S. C. H. van den Oord, A. F. L. Schinkel, Erasmus MC (Netherlands); N. de Jong, A. F. W. van der Steen, Erasmus MC (Netherlands) and Interuniversity Cardiology Institute of the Netherlands (Netherlands);

J. G. Bosch, Erasmus MC (Netherlands)

\section{SESSION 3 NOVEL BEAMFORMING APPROACHES}

8320 OD Generation of limited-diffraction wave by approximating theoretical X-wave with simple driving [8320-12]

Y. Li, M. Ding, S. Hua, Y. Ming, Huazhong Univ. of Science and Technology (China)

$8320 \mathrm{OE}$ Adaptive minimum variance beamforming combined with phase coherence imaging for ultrasound imaging [8320-13]

M. XU, Y. Chen, M. Ding, Y. Ming, Huazhong Univ. of Science and Technology (China)

8320 OF Preliminary comparison of 3D synthetic aperture imaging with Explososcan [8320-50]

M. F. Rasmussen, J. M. Hansen, Technical Univ. of Denmark (Denmark); G. Férin, R. Dufait, Vermon S.A. (France); J. A. Jensen, Technical Univ. of Denmark (Denmark)

8320 OG FPGA implementation of robust Capon beamformer [8320-15]

X. Guan, H. Zmuda, J. Li, L. Du, M. Sheplak, Univ. of Florida (United States)

$8320 \mathrm{OH}$ Detection of breast microcalcifications using synthetic-aperture ultrasound [8320-16] L. Huang, Y. Labyed, Y. Lin, Z. Zhang, Los Alamos National Lab. (United States); J. Pohl, D. Sandoval, M. Williamson, Univ. of New Mexico (United States)

\section{SESSION 4 CLINICAL APPLICATIONS AND DIAGNOSTICS}

832001 Frequency, bandwidth, and information transfer in B-mode imaging [8320-17]

C. K. Abbey, Univ. of California, Santa Barbara (United States); N. Q. Nguyen, M. F. Insana, Univ. of Illinois at Urbana-Champaign (United States) 
8320 0J Age and gender related differences in aortic blood flow [8320-18] M. S. Enevoldsen, Technical Univ. of Denmark (Denmark); M. M. Pedersen, Copenhagen Univ. Hospital Rigshopitalet (Denmark); M. C. Hemmsen, Technical Univ. of Denmark (Denmark); L. Lönn, Copenhagen Univ. Hospital Rigshopitalet (Denmark); K.-Å. Henneberg, J. A. Jensen, Technical Univ. of Denmark (Denmark)

8320 OK Clinical evaluation of synthetic aperture sequential beamforming [8320-19]

P. M. Hansen, Copenhagen Univ. Hospital Rigshopitalet (Denmark); M. C. Hemmsen, Technical Univ. of Denmark (Denmark) and BK Medical (Denmark); T. Lange, Univ. of Copenhagen (Denmark); J. M. Hansen, Technical Univ. of Denmark (Denmark); M. B. Nielsen, Copenhagen Univ. Hospital Rigshopitalet (Denmark); J. A. Jensen, Technical Univ. of Denmark (Denmark)

$8320 \mathrm{OL}$ Thoracic wall reconstruction using ultrasound images to model/bend the thoracic prosthesis for correction of pectus excavatum [8320-20]

J. G. Fonseca, A. H. J. Moreira, P. L. Rodrigues, Univ. do Minho (Portugal) and PT Government Associate Lab. (Portugal); J. C. Fonseca, A. C. M. Pinho, Univ. do Minho (Portugal);

J. Correia-Pinto, Univ. do Minho (Portugal) and PT Government Associate Lab. (Portugal);

N. F. Rodrigues, Polytechnic Institute of Cávado and Ave (Portugal) and Univ. do Minho (Portugal); J. L. Vilaça, Univ. do Minho (Portugal), PT Government Associate Lab. (Portugal), and Polytechnic Institute of Cávado and Ave (Portugal)

8320 OM Comparison of naïve Bayes and logistic regression for computer-aided diagnosis of breast masses using ultrasound imaging [8320-21]

T. W. Cary, A. Cwanger, S. S. Venkatesh, E. F. Conant, C. M. Sehgal, The Univ. of Pennsylvania (United States)

$83200 \mathrm{~N} \quad$ Ultrasound image-based respiratory motion tracking [8320-22]

Y. Hwang, J.-B. Kim, Y. S. Kim, W.-C. Bang, J. D. K. Kim, C. Kim, Samsung Advanced Institute of Technology (Korea, Republic of)

\section{SESSION $5 \quad$ ULTRASOUND COMPUTER TOMOGRAPHY: APPLICATION}

832000 Breast ultrasound tomography: bridging the gap to clinical practice [8320-23]

N. Duric, P. Littrup, C. Li, O. Roy, S. Schmidt, Karmanos Cancer Institute, Wayne State Univ. (United States) and Delphinus Medical Technologies (United States); R. Janer, X. Cheng, J. Goll, Karmanos Cancer Institute, Wayne State Univ. (United States); O. Rama,

L. Bey-Knight, Karmanos Cancer Institute, Wayne State Univ. (United States) and Delphinus Medical Technologies (United States); W. Greenway, Karmanos Cancer Institute, Wayne State Univ. (United States)

8320 OP Automatic multimodal 2D/3D image fusion of ultrasound computer tomography and x-ray mammography for breast cancer diagnosis [8320-24]

T. Hopp, Karlsruhe Institute of Technology (Germany); N. Duric, Karmanos Cancer Institute (United States); N. V. Ruiter, Karlsruhe Institute of Technology (Germany) 
$83200 Q$ Breast tissue composition and breast density measurements from ultrasound tomography [8320-26]

M. Sak, Karmanos Cancer Institute, Wayne State Univ. (United States); N. Duric, Karmanos Cancer Institute, Wayne State Univ. (United States) and Delphinus Medical Technologies (United States); N. Boyd, Princess Margaret Hospital (Canada); P. Littrup, Karmanos Cancer Institute, Wayne State Univ. (United States) and Delphinus Medical Technologies (United States); E. West, Delphinus Medical Technologies (United States); C. Li, Karmanos Cancer Institute, Wayne State Univ. (United States) and Delphinus Medical Technologies (United States)

8320 OR Multi-grid tomographic inversion for breast ultrasound imaging [8320-40]

C. Li, Delphinus Medical Technologies (United States); A. Stewart, Innovative Pivotal Applications (United States); N. Duric, Delphinus Medical Technologies (United States) and Karmanos Cancer Institute (United States)

\section{SESSION 6 KEYNOTE AND ULTRASOUND GUIDED PROCEDURES}

8320 OS Integration of 3D intraoperative ultrasound for enhanced neuronavigation (Keynote Paper) [8320-28]

K. D. Paulsen, Thayer School of Engineering at Dartmouth (United States) and Dartmouth-Hitchcock Medical Ctr. (United States); S. Ji, A. Hartov, X. Fan, Thayer School of Engineering at Dartmouth (United States); D. W. Roberts, Dartmouth-Hitchcock Medical Ctr. (United States)

8320 OT Towards intraoperative monitoring of ablation using tracked 3D ultrasound elastography and internal palpation [8320-29]

P. Foroughi, The Johns Hopkins Univ. (United States); J. Burgner, Vanderbilt Univ. (United States); M. A. Choti, Johns Hopkins Medical Institutions (United States); R. J. Webster III, Vanderbilt Univ. (United States); G. D. Hager, The Johns Hopkins Univ. (United States); E. M. Boctor, The Johns Hopkins Univ. (United States) and Johns Hopkins Medical Institutions (United States)

$8320 \mathrm{OU}$ A new automatic landmark extraction framework on ultrasound images of femoral condyles [8320-30]

A. Masson-Sibut, Univ. Paris Est Créteil (France) and Aesculap SAS (France); A. Nakib, E. Petit, Univ. Paris Est Créteil (France); F. Leitner, Aesculap SAS (France)

\section{SESSION 7 ULTRASOUND FUNCTIONAL IMAGING}

8320 OV High-frequency subharmonic emission with chirp-coded excitation: implications for imaging [8320-31]

H. Shekhar, M. M. Doyley, Univ. of Rochester (United States)

$8320 \mathrm{OW}$ Self-demodulation effect on subharmonic response of ultrasound contrast agent [8320-32]

V. Daeichin, Erasmus MC (Netherlands) and Chalmers Univ. of Technology (Sweden);

T. Faez, Erasmus MC (Netherlands); A. Needles, Visualsonics Inc. (Canada); G. Renaud, J. G. Bosch, Erasmus MC (Netherlands); A. F. W. van der Steen, N. de Jong, Erasmus MC (Netherlands) and Interuniversity Cardiology Institute of the Netherlands (Netherlands) 
8320 0X Motion compensation of ultrasonic perfusion images [8320-33]

S. Schäfer, Otto-von-Guericke-Univ. Magdeburg (Germany); K. Nylund, O. H. Gilja, Institute of Medicine, Univ. of Bergen (Norway) and Helse Bergen Haukeland Univ. Hospital

(Norway); K. D. Tönnies, Otto-von-Guericke-Univ. Magdeburg (Germany)

8320 OY A high frequency ultrasound aided study of kinetics of drug delivery in tumor models [8320-34]

S. Torosean, B. Flynn, Thayer School of Engineering at Dartmouth (United States);

K. S. Samkoe, Dartmouth Hitchcock Medical Ctr. (United States); J. Gunn, J. Axelsson, Thayer School of Engineering at Dartmouth (United States); M. Doyley, Univ. of Rochester (United States); B. W. Pogue, Thayer School of Engineering at Dartmouth (United States) and Dartmouth Hitchcock Medical Ctr. (United States)

$8320 \mathrm{OZ} \quad$ Novel ultrasound elastography system for multifocal breast cancer assessment [8320-35] S. Shavakh, The Univ. of Western Ontario (Canada); A. Fenster, Robarts Research Institute (Canada) and The Univ. of Western Ontario (Canada); A. Samani, The Univ. of Western Ontario (Canada) and Robarts Research Institute (Canada)

832010 Tendon strain imaging using non-rigid image registration: a validation study [8320-36] N. M. Almeida, P. Slagmolen, D. Barbosa, Katholieke Univ. Leuven (Belgium); L. Scheys, Smith \& Nephew European Ctr. for Knee Research (Belgium); L. Geukens, Katholieke Univ. Leuven (Belgium); S. Fukagawa, Univ. Hospitals Leuven (Belgium); K. Peers, Katholieke Univ. Leuven (Belgium); J. Bellemans, Univ. Hospitals Leuven (Belgium); P. Suetens, J. D'Hooge, Katholieke Univ. Leuven (Belgium)

$832011 \quad$ Multi-scale AM-FM motion analysis of ultrasound videos of carotid artery plaques [8320-37] S. Murillo, VisionQuest Biomedical, LLC (United States); V. Murray, The Univ. of New Mexico (United States); C. P. Loizou, Intercollege Limassol Campus (Cyprus); C. S. Pattichis, Univ. of Cyprus (Cyprus); M. Pattichis, The Univ. of New Mexico (United States); E. S. Barriga, VisionQuest Biomedical, LLC (United States)

\section{POSTER SESSION}

832012 A new directional demodulation method for vector Doppler imaging [8320-14] K.-W. Jeon, S. Yoon, Sogang Univ. (Korea, Republic of); Y. Kim, H. Shim, Samsung Electronics Co., Ltd. (Korea, Republic of); Y. Yoo, G.-D. Kim, T.-K. Song, Sogang Univ. (Korea, Republic of)

832013 Investigation and optimization of a finite element simulation of transducer array systems for 3D ultrasound computer tomography with respect to electrical impedance characteristics [8320-38]

B. Kohout, Karlsruhe Institute of Technology (Germany); J. Pirinen, Karlsruhe Institute of Technology (Germany) and Savonia Univ. of Applied Sciences (Finland); N. V. Ruiter, Karlsruhe Institute of Technology (Germany)

832014 3D refraction-corrected transmission reconstruction for 3D ultrasound computer tomography [8320-39]

R. Dapp, H. Gemmeke, N. Ruiter, Karlsruhe Institute of Technology (Germany)

832015 Ultrasound assisted optical tomography: estimation of phase shift experienced by photon on transit through US insonified region for detection of breast tumor [8320-41]

S. Singh, R. Kanhirodan, R. M. Vasu, Indian Institute of Science (India) 
832016 Modulus reconstruction from prostate ultrasound images using finite element modeling [8320-42]

Z. Yan, S. Zhang, Rutgers, The State Univ. of New Jersey (United States); S. K. Alam, Riverside Research (United States); D. N. Metaxas, Rutgers, The State Univ. of New Jersey (United States); B. S. Garra, U.S. Food and Drug Administration (United States); E. J. Feleppa, Riverside Research (United States)

832017 Out-of-plane motion estimation based on a Rician-Inverse Gaussian model of RF ultrasound signals: speckle tracking without fully developed speckle (Cum Laude Poster Award) [8320-43]

N. Afsham, M. Najafi, P. Abolmaesumi, R. Rohling, The Univ. of British Columbia (Canada)

832018 Ultrasound imaging of the mouse pancreatic duct using lipid microbubbles [8320-44] B. Banerjee, The Univ. of Arizona (United States) and College of Optical Sciences, The Univ. of Arizona (United States); K. R. McKeown, The Univ. of Arizona (United States); B. Skovan, Arizona Cancer Ctr., The Univ. of Arizona (United States); E. Ogram, P. Ingram, The Univ. of Arizona (United States); N. Ignatenko, G. Paine-Murrieta, Arizona Cancer Ctr., The Univ. of Arizona (United States); R. Witte, T. O. Matsunaga, The Univ. of Arizona (United States)

832019 Ultrasound imaging of extended targets using a windowed time-reversal MUSIC method [8320-45]

Y. Labyed, L. Huang, Los Alamos National Lab. (United States)

8320 1A Reconfigurable 2D cMUT-ASIC arrays for 3D ultrasound image [8320-46] J. Song, Samsung Electronics Co., Ltd. (Korea, Republic of); S. Jung, Hanyang Univ. (Korea, Republic of); Y. Kim, K. Cho, B. Kim, S. Lee, Samsung Electronics Co., Ltd. (Korea, Republic of); J. Na, I. Yang, O. Kwon, Hanyang Univ. (Korea, Republic of); D. Kim, Samsung Electronics Co., Ltd. (Korea, Republic of)

8320 1B Evaluation of a fractional filter-based receive beamforming method for low-cost ultrasound color Doppler imaging [8320-47]

H. Yang, Sogang Univ. (Korea, Republic of); J. Kang, Sogang Univ. of Advanced Technology (Korea, Republic of); J. H. Chang, Sogang Univ. of Adavanced Technology (Korea, Republic of) and Sogang Univ. (Korea, Republic of); Y. Yoo, Sogang Univ. (Korea, Republic of)

8320 1C New synthetic aperture imaging technique with dynamic apodization window [8320-48] D. Kim, J. Park, J. Cho, T.-K. Song, Y. Yoo, Sogang Univ. (Korea, Republic of)

8320 1D New direct pixel beamforming based on phase rotation [8320-49]

Y. Kim, W. Lee, Y. Lee, Y. Yoo, Sogang Univ. (Korea, Republic of)

$8320 \mathrm{lE} \quad$ Ultrasound imaging software framework for real-time monitoring of acoustic ablation therapy [8320-51]

H.-J. Kang, N. P. Deshmukh, P. Stolka, The Johns Hopkins Univ. (United States); E. C. Burdette, Acoustic MedSystems, Inc. (United States); E. M. Boctor, The Johns Hopkins Univ. (United States)

$8320 \mathrm{lF}$ Software framework of a real-time pre-beamformed RF data acquisition of an ultrasound research scanner [8320-52]

H.-J. Kang, N. Kuo, X. Guo, D. Song, J. U. Kang, E. M. Boctor, The Johns Hopkins Univ. (United States) 
$83201 G \quad$ Post-processing multiple-frame super-resolution in ultrasound imaging [8320-53]

R. Morin, A. Basarab, M. Ploquin, D. Kouamé, Institut de Recherche en Informatique de Toulouse, CNRS, Univ. of Toulouse III (France)

$83201 \mathrm{H} \quad$ Local binary pattern texture-based classification of solid masses in ultrasound breast images [8320-54]

M. M. S. Matsumoto, C. M. Sehgal, J. K. Udupa, Perelman School of Medicine, The Univ. of Pennsylvania (United States)

832011 GPU accelerated implementation of ultrasound radio-frequency time series analysis [8320-55]

J. Chung, The Univ. of British Columbia (Canada); M. I. Daoud, The Univ. of British Columbia (Canada) and German Jordanian Univ. (Jordan); F. Imani, P. Mousavi, Queen's Univ.

(Canada); P. Abolmaesumi, The Univ. of British Columbia (Canada)

$83201 \mathrm{~J} \quad$ Ultrasound speckle reduction using nonlinear Gaussian filters and nonlocal neighbourhoods [8320-56]

S. Ramachandran, Network Systems \& Technologies (P) Ltd. (India); M. G. Nair, Varkala Government Hospital (India)

$83201 \mathrm{~K} \quad$ Robust dynamic programming method for ultrasound elastography [8320-57]

I. Fleming, H. Rivaz, The Johns Hopkins Univ. (United States); E. Boctor, Johns Hopkins Medical Institutions (United States); G. Hager, The Johns Hopkins Univ. (United States)

$83201 \mathrm{~L} \quad$ Evaluation of finite-element-based simulation model of photoacoustics in biological tissues [8320-58]

Z. Wang, S. Ha, K. Kim, Univ. of Pittsburgh (United States) and Univ. of Pittsburgh Medical Ctr. (United States)

Author Index 
Proc. of SPIE Vol. $8320832001-10$

Downloaded From: https://www.spiedigitallibrary.org/conference-proceedings-of-spie on 26 Apr 2023 Terms of Use: https://www.spiedigitallibrary.org/terms-of-use 


\title{
Conference Committee
}

\author{
Symposium Chairs
}

Joseph M. Reinhardt, The University of lowa (United States)

Nico Karssemeijer, Radboud University Nijmegen Medical Center (Netherlands)

Conference Chairs

Johan G. Bosch, Erasmus University Rotterdam (Netherlands)

Marvin M. Doyley, University of Rochester (United States)

Program Committee

Jeffrey C. Bamber, The Royal Marsden NHS Foundation Trust (United Kingdom)

Jan D'Hooge, Katholieke Universiteit Leuven (Belgium)

Nebojsa Duric, Karmanos Cancer Institute (United States) and Delphinus Medical Technologies (United States)

Stanislav Y. Emelianov, The University of Texas at Austin (United States)

James F. Greenleaf, Mayo Clinic (United States)

Michael F. Insana, University of Illinois at Urbana-Champaign (United States)

Jørgen A. Jensen, Technical University of Denmark (Denmark)

Stephen A. McAleavey, University of Rochester (United States)

Kirk K. Shung, The University of Southern California (United States)

Kai E. Thomenius, General Electric Company (United States)

William F. Walker, University of Virginia (United States)

\section{Session Chairs}

$1 \quad$ Ultrasound Computer Tomography: Novel Technology

Nebojsa Duric, Karmanos Cancer Institute (United States) and

Delphinus Medical Technologies (United States)

2 Ultrasound Image Processing

Johan G. Bosch, Erasmus University Rotterdam (Netherlands)

3 Novel Beamforming Approaches

Johan G. Bosch, Erasmus University Rotterdam (Netherlands)

$4 \quad$ Clinical Applications and Diagnostics

Craig K. Abbey, University of California, Santa Barbara (United States)

Johan G. Bosch, Erasmus University Rotterdam (Netherlands) 
$5 \quad$ Ultrasound Computer Tomography: Application

Nicole V. Ruiter, Karlsrue Institute of Technology (Germany)

$6 \quad$ Keynote and Ultrasound Guided Procedures

Kenneth H. Wong, Virginia Polytechnic Institute and State University

(United States)

Marvin M. Doyley, University of Rochester (United States)

$7 \quad$ Ultrasound Functional Imaging

Marvin M. Doyley, University of Rochester (United States) 